\title{
Evaluasi Pascapelatihan pada Kelompok Tani Hutan Pemegang Izin Perhutanan Sosial di Jawa Barat dan Jawa Tengah Tahun 2019
}

\section{(Post Training Evaluation of Forest Farmer Group of Having Social Forestry License in West Java and Central Java in 2019)}

\author{
Amin Fauzi \\ Balai Diklat Lingkungan Hidup dan Kehutanan Kadipaten, Sawala Kotak Pos 11, Jl. Raya Timur, Cipaku, Kadipaten, \\ Majalengka, Jawa Barat 45452. \\ Penulis korespondensi: elfauzi68@gmail.com \\ Diterima Desember 2019/Disetujui Juli 2020
}

\begin{abstract}
ABSTRAK
Perhutanan sosial adalah sistem pengelolaan hutan lestari yang dilaksanakan oleh masyarakat setempat dalam wadah Kelompok Tani Hutan (KTH) untuk meningkatkan kesejahteraan masyarakat, keseimbangan lingkungan, dan dinamika sosial budaya. Balai Diklat Lingkungan Hidup dan Kehutanan (BDLHK) Kadipaten menyelenggarakan pelatihan untuk mendukung program perhutanan sosial pada KTH pemegang izin perhutanan sosial dan dilaksanakan pada bulan Agustus-Oktober 2018 di Jawa Barat dan Jawa Tengah. Evaluasi pascadiklat dilaksanakan satu tahun setelah pelaksanaan pelatihan, mulai bulan Juni-Agustus 2019. Evaluasi pascadiklat bertujuan mengkaji kesesuaian materi pelatihan dengan kebutuhan usaha tani dan manfaat pelatihan terhadap usaha tani yang dikembangkan KTH. Pengambilan data dilakukan melalui metode wawancara dan menggunakan kuesioner. Analisis data menggunakan analisis deskriptif. Hasil evaluasi pelatihan pengukuran dan pemetaan partisipatif areal perhutanan sosial, teknik agroforestry, budi daya jamur tiram, pembuatan, pengemasan dan pemasaran bokashi, serta pemandu wisata alam menunjukkan aspek relevansi pelatihan dan manfaat pelatihan berada pada kategori sedang dan tinggi. Untuk meningkatkan kualitas proses dan hasil pelatihan, analisis kebutuhan pelatihan perlu dilakukan lebih cermat agar program pelatihan sesuai dengan kebutuhan masyarakat sasaran.
\end{abstract}

Kata kunci: kelompok tani hutan, manfaat pelatihan, perhutanan sosial

\begin{abstract}
Social forestry is sustainable forest management system implemented by local communities of Forest Farmer Group (FFG) aiming to increase community welfare, environmental balance and social cultural dynamics. Environment and Forestry Training Center Kadipaten conducted training to support social forestry programs with on-site model and was held August-October 2018 in West Java and Central Java. The post-training evaluation was conducted one year after the training finished from June-August 2019. The post-training evaluation aims to assess the suitability of the training materials with the needs of the farming business and the benefits of the training on the farming business developed by KTH. Data collection is done through questionnaires and interviews. The data analysis used descriptive analysis. The evaluation results on several training, i.e measurement and participatory mapping of social forestry areas, agroforestry engineering, oyster mushroom cultivation, making, packaging and marketing of bokashi, and nature tour guide showed that aspects of the relevance of the training to the needs of farming businesses are in the medium to high categories. The benefits of training to the farming businesses are in the medium and high category. To improve the quality of the training process and results, it is necessary to conduct a more careful analysis of training needs so that the training program is in line with the needs of the target community.
\end{abstract}

Keywords: forest farmer groups, social forestry, the benefits of training

\section{PENDAHULUAN}

Perhutanan sosial adalah sistem pengelolaan hutan lestari yang dilaksanakan dalam kawasan hutan negara atau hutan hak/hutan adat yang dilaksanakan masyarakat setempat untuk meningkatkan kesejahteraannya, keseimbangan lingkungan, dan dinamika sosial budaya (Peraturan Menteri Lingkungan Hidup dan Kehutanan No. P.83/2016). Pemerintah mengalokasikan 12,7 juta ha untuk perhutanan sosial, melalui skema hutan desa, hutan kemasyarakatan, hutan 
tanaman rakyat, hutan adat dan kemitraan kehutanan (KK) dalam bentuk Pengakuan Perlindungan Kemitraan Kehutanan (KULIN KK) atau Izin Pemanfaatan Hutan Perhutanan Sosial (IPHPS) di Pulau Jawa. Permen LHK No. P.83/ 2016 dan No. P.39/2017 menegaskan sejumlah kewajiban pemegang izin perhutanan sosial, antara lain melakukan penanaman dan pemeliharaan hutan di areal kerja, mempertahankan fungsi hutan, dan perlindungan hutan.

Berdasarkan data dari Direktorat Jenderal Perhutanan Sosial dan Kemitraan Lingkungan (PSKL), sampai akhir Desember 2019 program perhutanan sosial telah mencapai areal seluas 3,43 juta ha untuk sekitar 773.395 KK dengan total 6.156 unit Surat Keputusan (SK) (Hadi 2020). Agar dampak implementasi program perhutanan sosial dapat dirasakan secara nyata oleh petani pemegang izin, lembaga masyarakat desa hutan (LMDH) ataupun kelompok tani hutan (KTH) yang akan menjadi pelaku utama program perhutanan sosial perlu dikembangkan kapasitas kelembagaan dan kewirausahaan dalam mengelola sumber daya hutan. Kelompok atau lembaga tersebut diharapkan dapat bertransformasi menjadi kelompok usaha perhutanan sosial (KUPS) yang mandiri (Hadi 2020).

Pelatihan dilakukan untuk meningkatkan kapasitas KTH pemegang izin perhutanan sosial, balai diklat LHK Kadipaten yang dilaksanakan di lokasi tempat KTH tersebut berdomisili (model on site) di Provinsi Jawa Barat dan Jawa Tengah pada tahun 2018. Pelatihan tersebut antara lain: budi daya tanaman bawah tegakan (emponempon), pemanfaatan jasa lingkungan dan wisata alam, budi daya pohon penghasil gaharu, pengukuran dan pemetaan partisipatif areal kerja perhutanan sosial, teknik agroforestry, pencegahan kebakaran hutan bagi masyarakat, budi daya jamur tiram, pembuatan, pengemasan, dan pemasaran bokashi, serta pemandu wisata alam. Metode kurikulum pelatihan terdiri atas $30 \%$ teori dan $70 \%$ praktik. Peserta pelatihan adalah pengurus dan anggota KTH pemegang izin perhutanan sosial. Semua pengajar pelatihan tersebut berasal dari widyaiswara BDLHK Kadipaten.

Pelatihan menurut Bernardin \& Russell (1998) adalah usaha untuk mengembangkan kinerja para pekerja berkaitan dengan pekerjaannya. Hal ini berkaitan dengan perubahan perilaku, sikap, keahlian, dan pengetahuan yang spesifik. Pengukuran ketercapaian tujuan pelatihan dengan melakukan evaluasi pasca- diklat yang dilaksanakan pada tahun anggaran 2019 atau satu tahun setelah pelatihan tersebut diselenggarakan. Tujuan evaluasi adalah untuk mengetahui kesesuaian materi pelatihan dengan kebutuhan peningkatan kompetensi petani anggota KTH dan manfaat pelatihan bagi pengembangan usaha tani petani anggota KTH.

\section{METODE PELAKSANAAN KEGIATAN}

\section{Lokasi dan Khalayak Sasaran}

Evaluasi pascadiklat (EPD) dilaksanakan di KTH di Jawa Barat meliputi Sumedang dan Indramayu serta Jawa Tengah meliputi Pemalang dan Boyolali. Evaluasi pascadiklat dilaksanakan selama 3 bulan mulai Juni-Agustus 2019. Sasaran evaluasi pascadiklat adalah para petani anggota KTH sebanyak 150 orang yang telah mengikuti pelatihan: pengukuran dan pemetaan partisipatif areal perhutanan sosial, teknik agroforestry, budi daya jamur tiram, pembuatan, pengemasan dan pemasaran bokashi serta pemandu wisata alam pada tahun 2018 yang diselenggarakan oleh BDLHK Kadipaten yang dilaksanakan di masingmasing KTH seperti disajikan pada Tabel 1.

\section{Teknik Pengambilan Sampel}

Teknik pengambilan sampel menggunakan probability sampling. Probability sampling adalah teknik sampling yang memberikan peluang yang sama bagi setiap unsur (anggota) populasi untuk dipilih menjadi anggota sampel. Teknik yang digunakan adalah simple random sampling. Setiap unit sampling sebagai unsur populasi memperoleh peluang yang sama untuk menjadi sampel atau untuk mewakili populasinya. Metode ini digunakan dengan asumsi anggota populasi dianggap homogen dan jumlah populasi yang tidak terlalu besar (Sugiyono 2010).

\section{Alat dan Bahan}

Alat dan bahan yang digunakan dalam evaluasi pascadiklat antara lain: kuesioner, panduan wawancara, alat rekam, buku catatan, dan laptop.

\section{Tahapan dan Metode Pelaksanaan Evaluasi Pascadiklat}

Kegiatan evaluasi pascadiklat terdiri atas bebrapa tahap, yaitu: konfirmasi baik lewat surat maupun lewat telepon kepada ketua-ketua KTH, pengambilan data di KTH dengan menggunakan kuesioner dan dilanjutkan dengan wawancara, pengumpulan data, dan analisis data evaluasi pascadiklat. Wawancara difokuskan pada aspek 
Tabel 1 Pelatihan masyarakat yang dilaksanakan oleh BDLHK Kadipaten Tahun 2018.

\begin{tabular}{|c|c|c|c|}
\hline Nama pelatihan & Waktu & Tempat & Lokasi \\
\hline $\begin{array}{l}\text { Pengukuran dan pemetaan } \\
\text { partisipatif areal kerja } \\
\text { perhutanan sosial }\end{array}$ & $\begin{array}{l}28-30 \text { Agustus } \\
2018\end{array}$ & Jawa Barat & $\begin{array}{l}\text { LMDH Paniis, Desa Pengadegan, } \\
\text { Kecamatan Rancakalong, Sumedang }\end{array}$ \\
\hline Teknik agroforestry & $\begin{array}{l}\text { 18-20 September } \\
2018\end{array}$ & Jawa Barat & $\begin{array}{lcr}\text { KTH Wana } & \text { Baru Mandiri, } & \text { Desa } \\
\text { Mekarwaru, } & \text { Kecamatan } & \text { Gantar } \\
\text { Indramayu } & & \\
\end{array}$ \\
\hline Budi daya jamur tiram & $\begin{array}{l}29-31 \text { Agustus } \\
2018\end{array}$ & Jawa Tengah & $\begin{array}{l}\text { KTH Wono Makmur I, Desa Gondang } \\
\text { Legi, Kecamatan Klego, Boyolali }\end{array}$ \\
\hline $\begin{array}{l}\text { Pembuatan, pengemasan, } \\
\text { dan pemasaran bokashi }\end{array}$ & $\begin{array}{l}\text { 18-20 September } \\
2018\end{array}$ & Jawa Tengah & $\begin{array}{l}\text { KTH Wono Lestari II, Desa Wono Harjo, } \\
\text { Kecamatan Kemusu Boyolali }\end{array}$ \\
\hline Pemandu wisata alam & 9-11 Oktober 2018 & Jawa Tengah & $\begin{array}{l}\text { KTH Gunung Gajah Lestari, Desa } \\
\text { Gongseng, Kecamatan Randudongkal, } \\
\text { Pemalang }\end{array}$ \\
\hline
\end{tabular}

materi pelatihan dan manfaat pelatihan bagi peserta.

\section{- Konfirmasi}

Konfirmasi dengan ketua KTH baik melalui surat maupun melalui telepon dilaksanakan 2 minggu sebelum evaluasi pascadiklat. Kegiatan ini dimaksudkan agar ketua-ketua KTH dapat mengkondisikan anggota KTH yang pernah mengikuti pelatihan untuk dapat berkumpul di sekretariat masing-masig KTH sesuai waktu yang disepakati. Konfirmasi juga untuk memastikan kehadiran anggota KTH pada saat pengambilan data.

\section{- Pengambilan data}

Pengambilan data menggunakan kesioner dan wawancara. Anggota KTH mengisi kuesioner yang telah disiapkan. Setelah selesai mengisi kuesioner, dilanjutkan dengan wawancara kepada seluruh alumni pelatihan yang hadir untuk mendapatkan data dan informasi secara lebih mendalam terkait dengan kegiatan pelatihan yang pernah diikuti. Wawancara difokuskan pada aspek kesesuaian materi dengan kebutuhan peningkatan kompetensi petani dan manfaat pelatihan bagi usaha tani yang dikelola para petani.

\section{- Analisis Data}

Analisis data terdiri atas reduksi data, penyajian data, dan pengambilan kesimpulan. Proses ini dilakukan pada saat menentukan rancangan dan perencanaan penelitian, sewaktu proses pengumpulan data sementara dan analisis awal, serta setelah tahap pengumpulan data akhir (Huberman 2009). Reduksi data merupakan proses pemilahan, pemusatan perhatian pada penyederhanaan, pengabstrakkan, dan transformasi data "kasar" yang muncul dari catatan-catatan tertulis di lapangan. Penyajian data merupakan konstruk informasi padat terstruktur yang memungkinkan pengambilan kesimpulan. Pengambilan kesimpulan juga diverifikasi selama penelitian berlangsung.

Analisis data menggunakan analisis deskriptif. Analisis deskriptif bertujuan untuk menggambarkan fenomena yang ada (data yang terkumpul) sebagaimana adanya. Data dikelompokan sesuai dengan kategori yang sudah ditetapkan kemudian disajikan dalam bentuk tabel dan histogram serta diiberi penjelasan atau verifikasi atas pengelompokan tersebut.

\section{HASIL DAN PEMBAHASAN}

\section{Kesesuaian Materi Pelatihan dengan Kebutuhan Usaha Tani}

Relevansi pelatihan adalah kesesuaian antara muatan kompetensi yang terdapat pada kurikulum pelatihan dengan kebutuhan peningkatan kompetensi yang menunjang kegiatan usaha tani responden. Dengan demikian, kurikulum pelatihan hendaknya disesuaikan dengan kebutuhan petani untuk mengembangkan usaha taninya. Berdasarkan hasil analisis data dapat diketahui tingkat relevansi pelatihan dengan kebutuhan usaha tani responden yang meliputi pelatihan pengukuran dan pemetaan partisipatif areal kerja perhutanan sosial, teknik agroforestry, budidaya jamur tiram, pembuatan, pengemasan dan pemasaran bokashi, dan pemandu wisata alam. Kesesuaian antara relevansi pelatihan dengan kebutuhan petani peserta terlihat pada Gambar 1.

- Pelatihan pengukuran dan pemetaan partisipatif areal kerja perhutanan sosial: dari 25 
Kesesuaian pelatihan dengan kebutuhan usaha tani petani

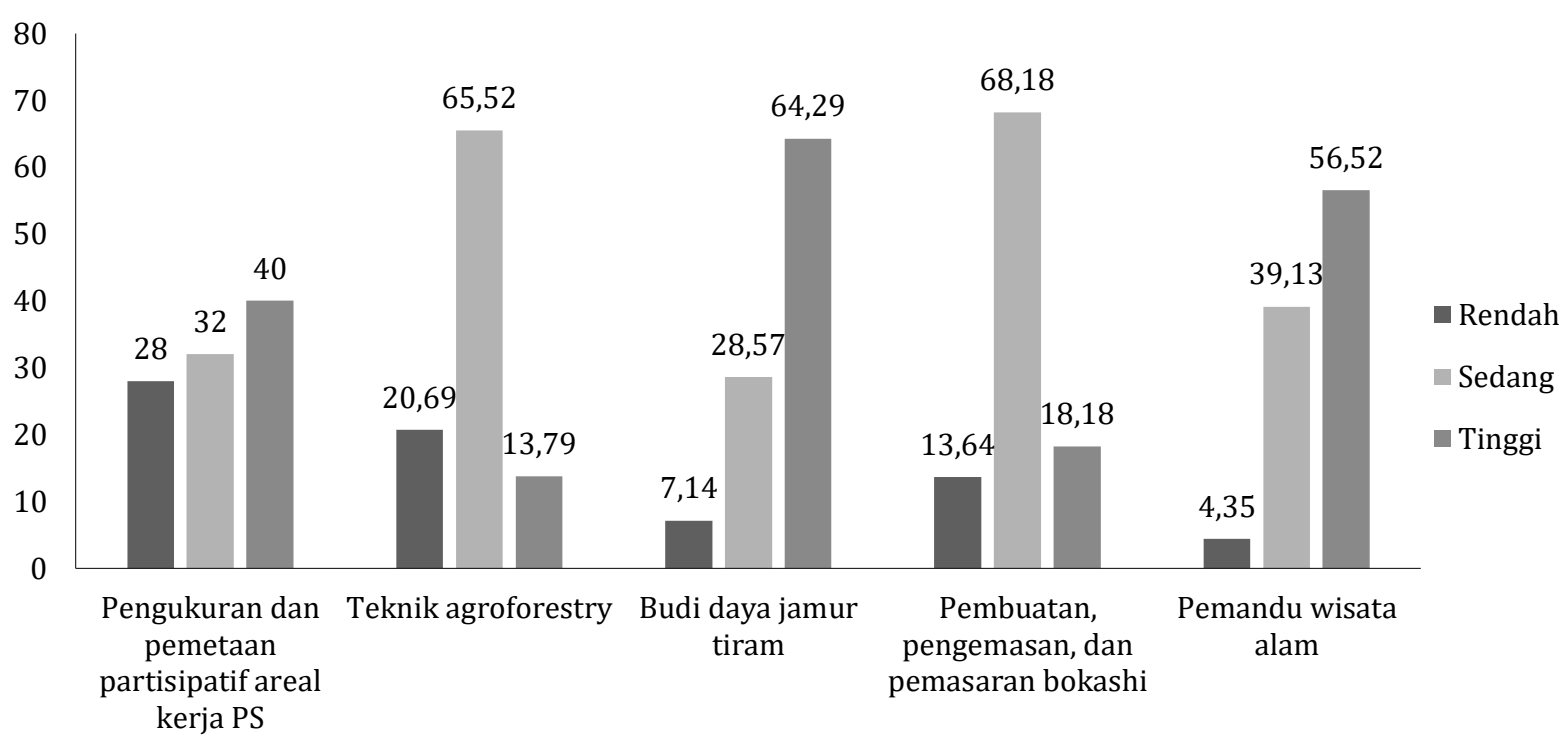

Gambar 1 Kesesuaian pelatihan dengan kebutuhan usaha tani responden.

responden yang mengikuti pelatihan, sebanyak 7 orang atau $(28 \%)$ menyatakan rendah, 8 orang $(32 \%)$ menyatakan sedang dan 10 orang $(40 \%)$ menyatakan kesesuaian mata ajar pelatihan dengan kebutuhan usaha tani atau pekerjaan responden termasuk kategori tinggi.

- Pelatihan teknik agroforestry: dari 29 orang responden alumni pelatihan, sebanyak 6 orang $(20,69 \%)$ menyatakan rendah, 19 orang $(65,52 \%)$ menyatakan sedang, dan 4 orang $(13,79 \%)$ menyatakan kesesuaian mata ajar pelatihan dengan kebutuhan pekerjaan atau usaha tani mereka tinggi. Suasana praktik pelatihan teknik agroforestry terlihat pada Gambar 2.

- Pelatihan budi daya jamur tiram: dari 14 responden, 1 orang $(7,14 \%)$ menyatakan rendah, 4 orang $(28,57 \%)$ menyatakan sedang dan 9 (64,29\%) menyatakan kesesuaian antara mata ajar pelatihan dengan kebutuhan usaha tani termasuk kategori tinggi.

- Pelatihan pembuatan, pengemasan, dan pemasaran bokashi: dari 22 orang responden, sebanyak 3 orang $(13,64 \%)$ menyatakan rendah, 15 orang $(68,18 \%)$ menyatakan sedang, dan 4 orang $(18,18 \%)$ menyatakan tinggi.

- Pelatihan pemandu wisata alam: dari 23 responden, 1 orang $(4,35 \%)$ menyatakan rendah, 9 orang $(39,13 \%)$ menyatakan sedang, dan 13 $(56,52 \%)$ menyatakan tinggi. Kegiatan

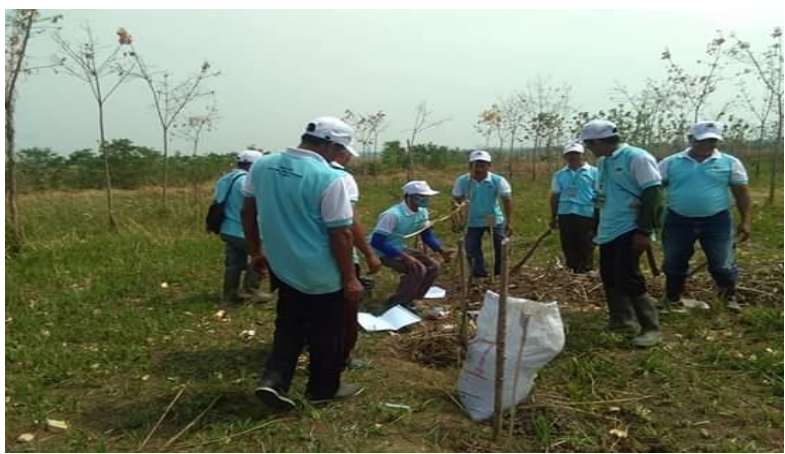

Gambar 2 Suasana praktik pelatihan teknik agroforestry.

pelatihan pemandu wisata alam terlihat pada Gambar 3.

\section{Manfaat Pelatihan terhadap Pengembangan Usaha Tani}

Manfaat pelatihan mengacu pada manfaat yang diperoleh peserta setelah selesai mengikuti suatu kegiatan pelatihan. Manfaat pelatihan bagi peserta mencakup peningkatan pengetahuan, keterampilan, dan sikap yang dapat mendukung pengembangan usaha tani petani peserta. Diharapkan pengetahuan dan keterampilan baru yang diperoleh setelah pelatihan dapat berkontribusi bagi peningkatan usaha tani mereka yang secara tidak langsung dapat berdampak bagi peningkatan pendapatan rumah tangga petani. Manfaat pelatihan juga berkaitan dengan peningkatan semangat petani dalam menjalankan usaha tani sesuai dengan jenis pelatihan yang pernah diikuti. Manfaat pelatihan terhadap 


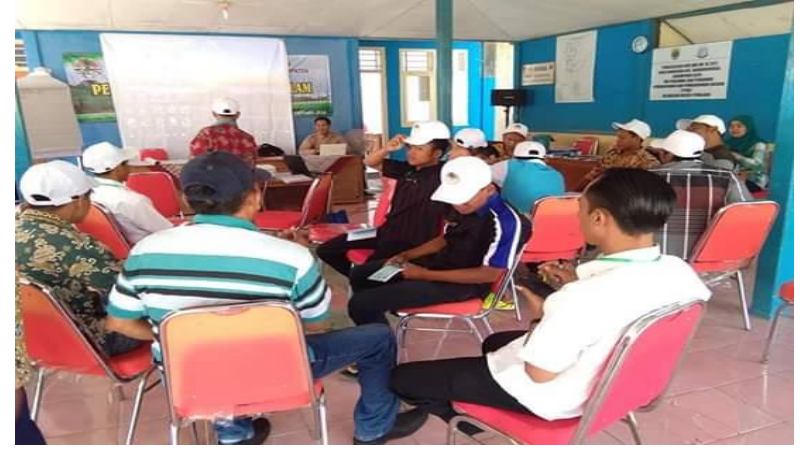

Gambar 3 Pelatihan pemandu wisata alam.

usaha tani responden pelatihan disajikan pada Gambar 4.

Kebutuhan pelatihan sebagai upaya untuk meningkatkan pengetahuan dan keterampilan tidak terelakkan lagi. Agar terjadi perubahan perilaku sebagai implementasi dimilikinya kompetensi oleh seseorang maka sistem pelatihan yang dilaksanakan hendaknya menggunakan perlakuan atau treatment yang menyentuh persepsi, konsep diri, dan nilai-nilai yang dimiliki oleh individu. Perubahan perilaku produktif membutuhkan proses yang panjang. Sebagaimana teori pembelajaran behavoiristik, untuk dapat mengubah perilaku, maka penguatan (reinforcement), pengulangan (repetition), dan pengarahan (coaching) dibutuhkan (Gasong 2018).

Relevansi berkaitan dengan kecocokan atau kesesuaian antara muatan pengalaman pembelajaran yang berisi seperangkat pengetahuan dan keterampilan yang termuat dalam dokumen kurikulum pelatihan dengan kebutuhan peningkatan kompetensi peserta pelatihan. Dalam konteks pendidikan, relevansi pendidikan adalah kesesuaian antara kemampuan/skill yang diperoleh melalui jenjang pendidikan dengan kebutuhan pekerjaan (Ali 2009). Dengan demikian, kurikulum atau program pendidikan haruslah disesuaikan dengan tuntutan hidup atau kebutuhan pekerjaan di kehidupan nyata.

Berdasarkan hasil penelitian terkait dengan aspek kesesuaian menunjukkan gambaran yang cukup beragam. Persepsi alumni kelima pelatihan terkait dengan kesesuaian pelatihan dengan kebutuhan usaha tani rata-rata berada pada kategori sedang sampai tinggi. Setelah dilakukan pengkajian secara lebih mendalam terkait dengan kebutuhan pelatihan, terdapat persepsi yang bertolak belakang antara kesesuaian pelatihan dengan kebutuhan pelatihan responden. Responden pelatihan pembuatan, pengemasan dan pemasaran bokashi walaupun persepsinya terhadap kesesuaian pelatihan dengan kebutuhan usaha tani sebesar 68,18\% berada pada kategori sedang dan 18,18\% tinggi, tetapi mereka sebenarnya lebih membutuhkan jenis pelatihan yang lain.

Data hasil wawancara diketahui bahwa responden pelatihan pembuatan, pengemasan, dan pemasaran pupuk bokashi lebih membutuhkan pelatihan lain yang terkait dengan potensi lokal yang ada di wilayah desa mereka. Berdasarkan hasil penelitian diketahui bahwa responden pelatihan di Desa Wonosegoro, Kecamatan Kemusu, Kabupaten Boyolali lebih membutuhkan pelatihan terkait dengan pengembangan dan pemanfaatan tanaman bambu. Kebutuhan pelatihan tentang bambu dilandasi oleh keterbatasan pengetahuan dan keterampilan dalam pengolahan bambu pada masyarakat, sementara sumber daya bambu sangat berlimpah di daerah ini. Hal ini menunjukkan terdapat ketidaksesuaian antara kebutuhan petani dengan pelatihan yang dilaksanakan dan mengindikasikan ketidaktepatan dalam melaksanakan analisis kebutuhan pelatihan sebelum pelatihan dilaksanakan.

Padahal melakukan analisis kebutuhan secara sistematis merupakan langkah awal yang penting dalam mendisain program pelatihan yang secara substansial berpengaruh terhadap efektivitas organisasi. Arthur Jr (2003) menjelaskan bahwa analisis kebutuhan merupakan proses penentuan kebutuhan pelatihan suatu organisasi dan merupakan upaya untuk menjawab pertanyaan apakah kebutuhan, tujuan, dan masalah organisasi dapat dipenuhi atau ditangani dengan pelatihan. Dengan demikian, melakukan penilaian kebutuhan yang sistematis adalah langkah awal yang penting untuk desain dan pengembangan pelatihan dan secara substansial dan dapat memengaruhi efektivitas keseluruhan program pelatihan.

Salah satu tugas fundamental dalam melakukan analisis kebutuhan adalah mengetahui keterampilan dan kompetensi yang benar-benar dibutuhkan oleh peserta pelatihan. Analisis kebutuhan tersebut kemudian menjadi dasar dalam mendisain pembelajaran. Laird (2003) menyatakan bahwa salah satu tugas mendasar dari proses mendesain pelatihan adalah melakukan penilaian kebutuhan, yaitu menentukan keterampilan atau kompetensi mana yang diperlukan dan keterampilan apa yang kurang dimiliki oleh karyawan. Kesenjangan keterampilan yang diidentifikasi menjadi fokus dari 
Manfaat pelatihan terhadap pengembangan usaha tani

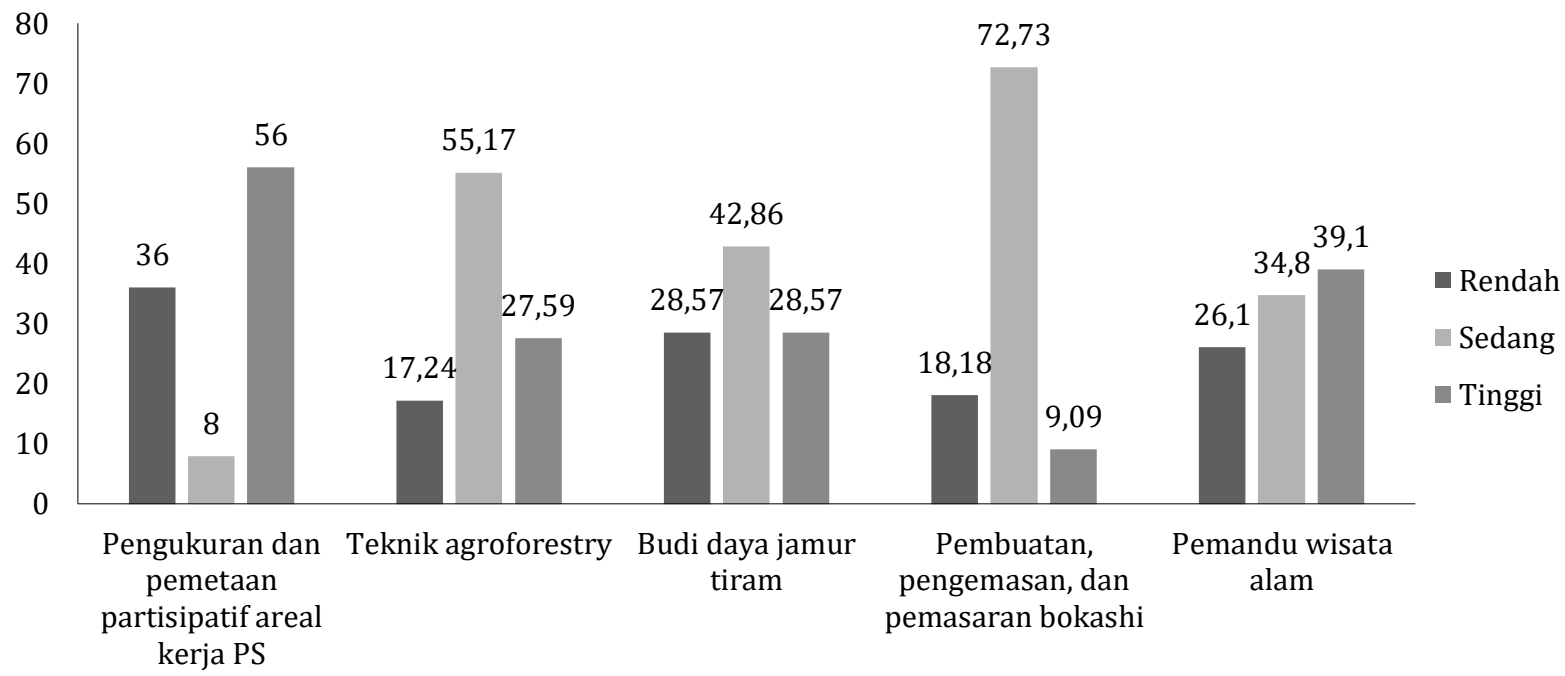

Gambar 4 Manfaat pelatihan terhadap pengembangan usaha tani.

pengalaman pembelajaran dan merupakan pijakan untuk mendesain pembelajaran.

Pelatihan yang tepat dengan sasaran yang tepat merupakan kondisi ideal yang diharapkan dapat menghasilkan efektivitas pelatihan. Dari pernyataan tersebut dapat dipahami bahwa terdapat keterkaitan yang saling memengaruhi antara komponen-komponen dalam program pelatihan. Ketepatan dalam melakukan analisis kebutuhan berimplikasi pada ketepatan dalam merencanakan kebutuhan pelatihan dan pemilihan orang-orang yang benar-benar membutuhkan pelatihan untuk peningkatan kinerjanya.

Schuler (1981) mengemukakan bahwa program yang efektif dapat dikembangkan dengan menggunakan prinsip belajar untuk menyesuaikan isi, desain, dan metode program untuk kebutuhan individu. Analisis kebutuhan merupakan basis dari program pelatihan dan menjadi salah satu faktor penentu keberhasilan pencapaian tujuan pelatihan. Ketepatan dalam mengidentifikasi permasalahan yang dihadapi petani merupakan salah satu kunci dalam pengembangan dan implementasi tindakan perbaikan secara tepat. Schuler (1981) mengemukakan bahwa keberhasilan pelaksanaan program pelatihan dan pengembangan tergantung pada pemilihan program yang tepat untuk orang yang tepat pada waktu yang tepat. Analisis kebutuhan membantu mengidentifikasi partisipan dan waktu yang tepat dalam pelaksanaan program pelatihan, sehingga program pelatihan sesuai dengan sasaran dan tujuan yang diharapkan.
Tujuan pelatihan adalah untuk meningkatkan pengetahuan, keterampilan, dan perubahan sikap. Pelatihan dapat meningkatkan kepercayaan diri, motivasi, dan komitmen staf, tanggung jawab, memberikan kepuasan pribadi dan prestasi, memperluas peluang bagi pekerjaan atau usaha tani, dan membantu untuk meningkatkan kualitas serta keterampilan para petani. Kegiatan pelatihan bertujuan untuk meningkatkan pengetahuan, sikap dan keterampilan peserta sesuai dengan tugas dan jabatannya untuk meningkatkan produktivitas dan kinerja individu maupun kelompok. Dengan demikian, hasil dari kegiatan pelatihan sebagai proses belajar adalah adanya perubahan perilaku, dari tidak tahu menjadi tahu, dari tidak mengerti menjadi mengerti, dari tidak mampu melaksanakan keterampilan tertentu menjadi mampu melaksanakannya. Perubahan tersebut hanya dapat dilihat dalam kegiatan bekerja setelah mengikuti pelatihan. Hasil pelatihan berupa peningkatan kemampuan melaksanakan pekerjaan hanya bermakna jika secara langsung atau tidak langsung mampu meningkatkan kemampuan kompetitif organisasi atau perusahaan (Nawawi 2011).

Jika pelatihan tidak mampu meningkatkan kemampuan kompetitif peserta pelatihan yang akan berpengaruh terhadap kemampuan kompetitif kelompok atau organisasi berarti terjadi inefisiensi dalam kegiatan pelatihan. Akibatnya, pelatihan menjadi kegiatan yang sekadar pemborosan waktu dan biaya. Kegiatan pelatihan akan mendatangkan manfaat bagi peserta atau dalam konteks ini para petani jika 
pengetahuan dan keterampilan baru yang diperoleh selama pelatihan dapat meningkatkan kinerja petani dalam pengelolaan usaha tani dan kinerja organisasi KTH.

Pelatihan di samping bermanfaat bagi peningkatan pengetahuan, sikap, dan keterampilan para peserta dan kemampuan untuk memecahkan masalah yang dihadapi dalam pekerjaannya, juga bermanfaat bagi peningkatan motivasi kerja. Pelatihan yang efektif berpotensi sangat besar untuk meningkatkan kompetensi petani agar mereka mampu memberikan kontribusi nyata dalam meningkatkan kinerja usaha taninya. Thang \& Truong (2009) mengemukakan, bahwa pelatihan dapat meningkatkan keterampilan teknis karyawan dan kemampuan mereka dalam memecahkan masalah. Pelatihan dapat juga memotivasi semangat kerja karyawan dan meningkatkan perilaku kerja karyawan

Hasil pelatihan menjadi positif, jika alumni pelatihan: a) Memiliki semangat yang lebih tinggi dalam mengelola usaha tani; b) Memahami situasi pekerjaan dan mampu menggunakan keterampilan baru secara tepat; dan c) Memiliki sikap berupa keyakinan yang besar bahwa pengetahuan dan keterampilan yang dimiliki dapat membantunya dalam memecahkan masalah yang berhubungan dengan usaha tani yang ditekuni.

\section{SIMPULAN}

Aspek relevansi pelatihan dengan kebutuhan usaha tani responden rata-rata berada pada kategori sedang sampai tinggi. Relevansi pelatihan pembuatan, pengemasan, dan pemasaran bokashi walaupun dominan pada kategori sedang $(68,18 \%)$ tetapi responden justru lebih membutuhkan jenis pelatihan lain yang berhubungan dengan potensi lokal yang melimpah di wilayah mereka, yaitu pemanfaatan dan pengolahan bambu. Manfaat pelatihan terhadap usaha tani responden rata-rata berada pada kategori sedang sampai tinggi. Manfaat pelatihan pengukuran dan pemetaan areal kerja perhutanan sosial dan pelatihan pemandu wisata alam terhadap usaha yang dikembangkan responden dominan berada pada kategori tinggi. Sedangkan pelatihan lainnya kecenderungan persepsi responden responden berada pada kategori sedang. Untuk meningkatkan efektivitas pelaksanaan dan manfaat pelatihan perlu dilakukan analisis kebutuhan pelatihan secara lebih cermat agar pelatihan yang diselenggarakan sesuai dengan kebutuhan petani sasaran.

\section{DAFTAR PUSTAKA}

Ali M. 2009. Pendidikan untuk Pembangunan Nasional. Jakarta (ID): Grasindo.

Arthur JrW, Bennett JrW,Edens PS, Bell ST. 2003. Effectiveness of Training in Organizations: A Meta-Analysis of Design and Evaluation Features. Journal of Applied Psychology. 88(2): 234-245. https://doi.org/10.1037/00219010.88.2.234

Bernardin HJ, Russell J. 1998. Human Resource Management, Second Edition. Singapore (SG): McGraw-Hill Book Co.

Gasong D. 2018. Belajar dan Pembelajaran. Yogyakarta (ID): Budi Utama.

Huberman AM, Miles MB. 2009. Manajemen Data dan Metode Analisis, eds. Norman Denzin K, Lincoln YS. Handbook of Qualitative Research terjemahan Dariyatno. Yogyakarta (ID): Pustaka Pelajar.

Hadi DW. 2020. KLHK Fokus Tingkatkan Kemampuan Masyarakat Pemegang Ijin Hutan Sosial. [Internet]. [diakses, 13 April 2020]. Tersedia pada: http://ppid.menlhk.go.id/siaran_pers/brows e/1857

[KLHK] Kementerian Lingkungan Hidup dan Kehutanan. Peraturan Menteri Lingkungan Hidup dan Kehutanan Nomor. P.83/MENLHK/ SETJEN/KUM. $1 / 10 / 2016 \quad$ Tentang Perhutanan Sosial.

[KLHK] Kementerian Lingkungan Hidup dan Kehutanan. Peraturan Menteri Lingkungan Hidup dan Kehutanan Nomor Nomor. P.39/MENLHK/ SETJEN/KUM. 1/6/2017 Tentang Perhutanan Sosial di Wilayah Kerja Perum Perhutani.

Laird D. 2003. Aproaches to Training and Development, third edition. Cambridge (US): Perseus Publishing.

Nawawi H. 2011. Manajemen Sumber Daya Manusia. Yogyakarta (ID): Gadjah Mada University Press.

Pejabat Pengelola Informasi dan Dokumentasi (PPID) Kementerian Lingkungan Hidup dan Kehutanan. KLHK Fokus Tingkatkan 
Kemampuan Masyarakat Pemegang Ijin Hutan Sosial. 2019. [Internet]. [Diunduhpada: 5 Desember 2019]. Tersedia pada: https://ppid.menlhk. go.id/siaran_ pers/browse/1857.

Schuler RS. 1981. Personel and Human Resource Management. Minnesota (USA): West Publishing.
Sugiyono. 2010. Metode Penelitian Kuantitatif, Kualitatif dan R\&D. Bandung (ID): Alfabeta.

Thang NN, Truong Q. 2011. The impact of training on firm performance in a transitional economy: Evidence from Vietnam. Research and Practice in Human Resource Management. 19(1): 11-24. 